\title{
Peningkatan Kualitas Pelayanan Perpustakaan Umum Melalui Pendekatan Sistem Lunak (Soft System) (Studi Pada Perpustakaan Umum Kota Kediri)
}

\author{
Dewi Purboningsih ${ }^{1}$, M.R.Khairul Muluk ${ }^{1.2}$, Irwan Noor ${ }^{1.2}$ \\ ${ }^{1}$ Program Magister IImu Administrasi Publik, Fakultas IImu Administrasi, Universitas Brawijaya \\ ${ }^{2}$ Fakultas IImu Administrasi, Universitas Brawijaya
}

\begin{abstract}
Abstrak
Peningkatan kualitas pelayanan perpustakaan umum merupakan suatu kegiatan yang berkelanjutan dilaksanakan untuk mempertahankan kelangsungan hidup organisasi tersebut. Penelitian ini bertujuan untuk mengidentifikasi, mendeskripsikan dan menganalisis proses peningkatan kualitas pelayanan Perpustakaan Umum Kota Kediri melalui pendekatan sistem lunak (soft system). Dalam proses peningkatan kualitas pelayanan perpustakaan tersebut, menyangkut permasalahan yang berkaitan dengan manjemen pelayanan dan penilaian pemustaka terhadap layanan perpustakaan. Maka, dalam proses peningkatan pelayanan perpustakaan umum, diperlukan suatu pengkajian yang mendalam terhadap masalah (problem) yang terjadi dalam organisasi tersebut melalui pendekatan sistem lunak. Hasil dari penelitian ini, permasalahan muncul dari manjemen pelayanan perpustakaan umum kota kediri, meliputi: jumlah tenaga atau staf dan pustakawan kurang memadai, terkendala pada anggaran sehingga banyak program pelayanan tidak berjalan, penggunaan sistem manual pada layanan sirkulasi menyebabkan pengelola kesulitan untuk memberikan informasi tentang ketersediaan buku, beberapa fasilitas kurang efektif dan tidak dimanfaatkan oleh pengunjung, dan tidak terpenuhinya kebutuhan pemustaka. Sehingga, salah satu rekomendasi dalam peningkatan kualitas pelayanan perpustakaan umum adalah penerapan model LSQ (Library Service Quality).
\end{abstract}

Kata kunci: Metodologi sistem lunak, Peningkatan kualitas pelayanan, Perpustakaan umum

\section{Abstract}

The improvement quality of public library service is a continue activities which is done to sustain life of organization. The purpose of this research to identify, describe and analyze the process of quality improvement public library of Kediri through soft system approach. In the process of quality improvement public library services, which it consists of the service management problems and assessment the quality from the perspective of users of the library. Therefore, in service improvement process of public organization and in particular, public library, required in-depth research to the problem that occurs in that organization through soft system approach. The result of this research, the problem arise from the management of public library service of Kediri, include : amount of staff and librarian which is inadequate, constrained on budget so that many service programs do not running on, the using of manual system in circulation service causes the difficulty to provide information about the availability of books, some facilities are not effective and not used by visitors, and not fulfilled the necessity of librarian. Thus, one of the recommendations to improve the quality of service public library is the application of a model LSQ ( library service quality ).

Keyword: Improvement of quality service, public library, soft system methodology

\section{PENDAHULUAN}

Penyelenggaraan pelayanan publik merupakan salah satu fungsi utama dalam penyelenggaraan pemerintah yang menjadi kewajiban aparatur pemerintah, berdasarkan Keputusan Menteri Pendayagunaan Aparatur Negara (Menpan) No. 63/Kep/M.PAN/7/2003[5] tertanggal 10 Juli 2003 pada paragraf 1 butir c menyebutkan pengertian pelayanan umum adalah segala kegiatan pelayanan yang dilaksanakan oleh instansi pemerintah sebagai upaya pemenuhan kebutuhan orang, masyarakat,

Corresponding Address:

Dewi Purboningsih

Email : Dewipurboningsih87@yahoo.co.id instansi pemerintah dan badan hukum maupun sebagai pelaksanaan ketentuan peraturan perundang-undangan. Salah satu tugas pemerintah adalah menyelenggarakan pelayanan publik dalam bidang layanan informasi dan pengetahuan. Salah satu organisasi publik tersebut adalah perpustakaan. Karena itu perpustakaan sebenarnya identik dengan pelayanan [1].

Sebagai organisasi publik, perpustakaan dituntut untuk memberikan pelayanan sesuai harapan para penggunanya, yaitu dapat

Alamat : Jl. Pradhana Bhakti No.212 Desa Kras Kecamatan Kras Kabupaten Kediri 64172 
menyediakan informasi yang aktual, tepat waktu dan mudah diakses sesuai dengan kebutuhan para pengguna jasa perpustakaan. Bahkan, para pustakawan pun dituntut untuk memiliki pengetahuan dan keahlian yang kompetitif terhadap kinerja mereka. Oleh karena itu, perpustakaan harus secara signifikan melakukan suatu perubahan dalam manajemen pelayanannya [2].

Manajemen pelayanan diperlukan oleh organisasi untuk meningkatkan kualitas pelayanan dan mempertahankan keberlangsungan hidup organisasi. Di era globalisasi sekarang ini informasi menjadi kekuatan yang harus diperhitungkan. Siapa saja yang menguasai informasi dengan baik akan menjadi pemenang dalam persaingan hidup di masyarakat. Perpustakaan merupakan lembaga yang berfungsi sebagai sumber informasi (source of information) yang dibutuhkan oleh masyarakat.

Manajemen pelayanan yang baik hanya akan dapat diwujudkan bila penguatan posisi tawarmenawar pengguna jasa palayanan mendapatkan prioritas utama. Model manajemen palayanan yang baik terdiri dari unsur-unsur antara lain: sumberdaya pelayanan, kultur organisasi, sistem pelayanan dan pelanggan. Dalam upaya peningkatan kualitas perpustakaan unsur-unsur yang mendapat perhatian antaralain: unsur unsur sumber daya pengelola, termasuk dalam tahapan input, unsur sistem pelayanan termasuk dalam proses, sedangkan unsur pelanggan termasuk dalam tahapan output. Kualitas atau mutu pelayanan pada perpustakaan sebaiknya mendapat perhatian mulai dari awal tahapan (input) sampai pada akhir tahapan manajemen.

Peningkatan kualitas pelayanan perpustakaan umum merupakan suatu kegiatan yang berkelanjutan dilaksanakan untuk mempertahankan kelangsungan hidup organisasi tersebut, sehingga perpustakaan dapat melaksanakan fungsinya, antara lain fungsi pendidikan, fungsi informati, fungsi penelitian, dan fungsi rekreatif. Oleh karena itu, peningkatan kualitas pelayanan perpustakaan umum sebaiknya mendapat perhatian besar terhadap pemerintah daerah dalam mengelola perpustakaan. Mengingat, kualitas perpustakaan umum di Indonesia berdasarkan dari hasil beberapa penelitian yang menunjukkan masih jauh dari harapan yang diinginkan.

Proses peningkatan pelayanan pada organisasi publik dan khususnya perpustakaan umum, diperlukan suatu pengkajian yang mendalam terhadap masalah (problem) yang terjadi dalam organisasi tersebut. Pengakajian tersebut dilakukan dengan menggunakan pendekatan soft system methodology. Soft system methodology sebuah pendekatan untuk memecahkan situasi masalah kompleks yang tidak terstruktur berdasarkan analisis holistik dan perpikir sistem [4]. Fokus soft system methodology adalah untuk menciptakan sistem aktivitas dan hubungan manusia dalam sebuah organisasi atau grup dalam rangka mencapai tujuan bersama.

Secara garis besar, operasionalisasi metodologi sistem lunak dalam upaya peningkatan kualitas pelayanan perpustakaan tersebut dikelompokan menjadi tiga tahap. Pertama, memahami masalah yang dihadapi dengan cara menggali masalah yang tidak terstruktur secara mendalam dan ditindaklanjutin dengan strukturisasi masalah (problem structural). Memahami masalah peningkatan kualitas pelayanan perpustakaan umum berdasarkan manjemen pelayanan yang terjadi pada Perpustakaan Umum Kota Kediri. Manajemen pelayanan tersebut, meliputi 3 (tiga unsur) yakni sumber daya, sistem pelayanan dan penilaian pengunjung terhadap layanan perpustakaan.

Kedua, menggali persepsi dari pihak-pihak yang terkait dengan masalah tersebut untuk membangun model cara pandang (world-views models) terhadap situasi permasalahan yang dihadapi secara sistemik dan upaya pemecahan masalah yang harus dilakukan. Membangun model cara pandang terhadap situasi permasalahan ini dilakukan dengan cara mendefinisikan sistem permasalahan (root definition). Berdasarkan penggalian persepsi ini kemudian dibangun model konseptual dengan bantuan model sistem formal atau kerangka berpikir sistem (system thinking).

Ketiga, menyempurnakan dan menguji keabsahan model sistem formal. Penyempurnaan model dilakukan dengan melalui cara membandingkan masalah dalam proses peningkatan kualitas pelayanan perpustakaan sesuai dengan realitas yang dihadapi. Hasil penyempurnaan model tersebut kemudian diuji keabsahannya melalui proses diskusi (debate) dengan komponen stakeholder sehingga dihasilkan model proses peningkatan kualitas pelayanan Perpustakaan Umum Kota Kediri. Model ini mempunyai keabsahan dan kelayakan untuk diterapkan, meskipun demikian penelitian ini tidak sampai melakukan pengujian model sistem yang telah disempurnakan ke dalam 
aplikasi proses peningkatan pelayanan Perpustakaan Umum Kota Kediri.

\section{METODE PENELITIAN}

Penelitian ini dirancang untuk mengkaji kompleksitas permasalahan terhadap peningkatan kualitas pelayanan perpustakaan dalam menyediakan layanan prima bagi pemustaka dan alternatif pemecahannya dengan menggunakan pendekatan sistem. Sehubungan dengan rancangan tersebut, penelitian ini dilaksanakan dalam dua tahap. Pertama, pelaksanaan penelitian dengan menggunakan metode kualitatif. Kedua, pelaksanaan penelitian dengan metodologi sistem lunak (Soft System Methodolgy) sebagai tindak lanjut penelitian tahap pertama.

Penelitian dilakukan di Perpustakaan Umum Kota Kediri. Teknik pengumpulan data dilakukan dengan cara observasi, interview dengan pengelola dan pengunjung perpustakaan umum kota kediri. Analisa penelitian ini dengan menggunakan analisa kualitatif, kemudian dilakukan analisis secara strukturisasi dengan berdasarkan tahapan-tahapan dalam soft system methodology (SSM). Operasionalisasi dari soft system methodology memiliki 7 (tujuh) tahapan yaitu:

1. Mengenali situasi permasalahan (the problem situation: unstructured)

2. Mengungkapkan situasi permasalahan (the problem situation: expressed)

3. Pembuatan definisi sistem permasalahan (root definitions of relevant)

4. Membangun model konseptual dengan situasi permasalahan (conceptual models)

5. Perbandingan model yang diinginkan (comparison of 4 with 2)

6. Perubahan model yang diinginkan (feasible, desirable, changes). Tahapan ke tujuh (tindakan perbaikan) tidak dilakukan dalam penelitian ini, karena tindakan perbaikan memerlukan waktu yang cukup lama. Disamping itu, penerapan tahapan ini juga menuntut adanya intervensi kebijakan menyangkut kemungkinan adanya perubahan struktur, perubahan prosedur dan perubahan sikap dari para pelaku kebijakan.

\section{HASIL DAN PEMBAHASAN}

\section{A. Mengungkapkan Situasi Permasalahan.}

Tahap ini diperlukan untuk strukturisasi permasalahan dan proses yang terjadi sebagai pusat perhatian penelitian (problem situatiation expressed), mengingat pada tahap pertama situasi permasalahan yang dikenali masih belum terstruktur. Strukturisasi permasalahan dimaksudkan untuk memahami masalah secara mendalam sesuai proses yang terjadi dalam realitas (real-world problem). Strukturisasi permasalahan dan proses yang terjadi sebagai pusat perhatian penelitian (problem situation expressed) berdasarkan pemahaman masalah yang telah dilakukan pada tahap pertama.

Strukur permasalahan yang dilakukan dalam penelitian menyangkut proses peningkatan kualitas pelayanan Perpustakaan Umum Kota Kediri berkaitan dengan manajemen pelayanan perpustakaan umum yang meliputi sumber daya yang tersedia, sistem pelayanan, dan pemustaka. Rumusan strukturisasi permasalahan dapat dirinci sebagai berikut:

1. Dalam proses kegiataan penggadaan koleksi buku, tahapan terhadap survei pemustaka belum pernah dilakukan. Selama ini, proses penggadaan buku hanya dilakukan oleh pengelola tidak menyesuaikan kebutuhan yang dikehendaki oleh pemustaka.

2. Proses pencairan anggaran untuk setiap kegiatan pelayanan memerlukan waktu yang lama dan birokrasi panjang sehingga pelaksanaan pelayanan perpustakaan menjadi terhambat.

3. Tidak adanya informasi yang jelas terkait fasilitas terhadap bentuk kegiatan layanan yang disediakan dalam perpustakaan.

4. Layanan sirkulasi masih menggunakan sistem manual. Sehingga, pengawasan pada ruang koleksi buku sulit dilakukan, karena tidak adanya sistem sensor pada pintu keluar-masuk ruang baca.

5. Pengelola juga mengalami kesulitan dalam memberikan informasi terhadap ketersediaan buku dalam proses dipinjam atau tidak.

6. Fungsi katalog tidak efektif, karena banyak pengunjung tidak mengetahui cara penggunaaan katalog.

7. Tidak adaya denda atau sanksi dalam setiap keterlambatan pengembalian buku. Sehingga, pemustaka tidak disiplin mengembalikan buku yang telah dipinjam.

8. Kurang reprensentatinya ruang koleksi anak, sempit dan tidak menarik.

9. Waktu pelayanan yang singkat

10. Tidak adanya rewad bagi pengelola yang disiplin dan punishment bagi pengelola tidak disiplin. 
11. Sistem mutasi pimpinan dan staf yang cepat. Sehingga, mempengaruhi kebijakan dan kinerja dalam perpustakaan.

12. Kurang mendapat perhatian dari pemerintah setempat.

\section{B. Mendefinisikan Sistem Permasalahan}

Tahapan ini adalah menyangkut pembuatan definisi mendasar tentang sistem permasalahan (root definition) dengan cara menggali permasalahan secara mendalam dari stakeholder dan pandangan idealnya untuk memecahkan masalah yang dihadapi. Tujuannya menggambarkan keterkaitan antara situasi permasalahan dengan esensi pemecaham masalah yang perlu dikerjakan. Dengan mendefinisikan sistem permasalahan yang terungkap mengenai apa yang dikerjakan, mengapa dikerjakan, siapa yang mengerjakan, siapa yang diuntungkan dengan pekerjaan tersebut, dan apakah lingkungan yang membatasi tindakan yand dilakukan.

Model dalam mendefinisikan sistem permasalahan tersebut dikenal dengan istilah CATWOE. Dalam sistem tersebut, inti atau core dari sistem permasalahan terletak pada transfomasi (transformation) dan cara pandang (world views). Artinya setiap komponen dalam model sistem definisi permasalahan tersebut mengacu pada dua kompenen inti tersebut ( $T$ dan W).

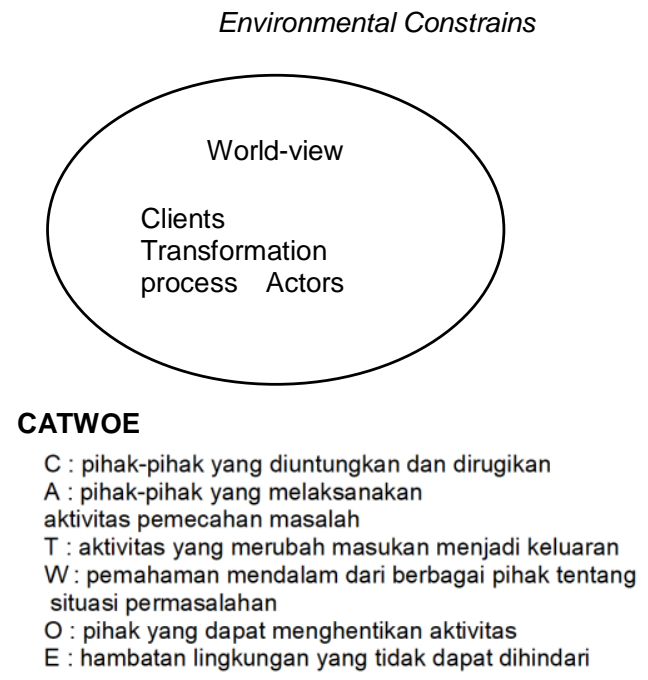

Gambar 1. Kerangka Mendefinisikan Sistem Permasalahan (Sumber: Checkland and Scholes (1990, h.35-36))

Menggali persepsi dari berbagai pihak dengan bantuan model analisis sistem CATWOE sebagaimana terlihat pada gambar 7 dapat membantu upaya memecahkan masalah yang telah distrukturisasi. Prinsip dasar yang dibangun dalam model ini adalah menentukan siapa yang melakukan aktivitas (actors) pemecahan masalah dan siapa yang dapat menghentikan aktivitas tersebut (owners). Actors dan Owners merupakan elemen dasar dalam model konseptual berpikir sistem. Actor adalah pihak-pihak yang memiliki keterampilan teknis dan diperlukan dalam aktivitas pemecahan masalah, sedangkan owners adalah pengambil keputusan yang lebih diperlukan untuk berpikir strategis daripada sebagai teknisi. Pihak-pihak yang memanfaatkan aktivitas bertujuan, pendorong dan penarik proses transformasi adalah Clients. Proses transformasi (transformation process) menyangkut aktivitas yang dapat merubah status quo kedalam suatu kondisi yang diharapkan. Sedangkan kendala lingkungan (environmental constrains) menyangkut kekuatan eksternal yang berpengaruh terhadap proses transformasi secara menyeluruh dan dapat merubah pandangan dalam menyikapi persoalan yang dihadapi. The world view merupakan representasi dalam mendefinisikan masalah serta upaya pemecahannya.

Sesuai dengan strukturisasi permasalahan, definisi sistem permasalahan berkaitan dengan proses peningkatan kualitas pelayanan Perpustakaan Umum Kota Kediri. Merujuk pada kerangka analisis CATWOE, rumusan definisi sistem permasalahan proses peningkatan kualitas pelayanan Perpustakaan Umum Kota Kediri pada tabel 1.

Penjelasan dari tabel.1 tentang definisi sistem permasalahan dalam proses peningkatan kualitas Perpustakaan Umum Kota Kediri, unsur clients (pihak-pihak yang diuntungkan atau dirugikan) dalam proses peningkatan pelayanan tersebut adalah pemustaka. Dalam model CATWOE terhadap peningkatan kualitas pelayanan perpustakaan umum tersebut, inti (core) dari komponen ini adalah proses peningkatan kualitas pelayanan. hal berkaitan, dengan rencana program otomasi dalam layanan sirkulasi yang belum terealisasi sampai tahun 2013, sehingga pengelola sebagai unsur (Actors) melakukan upaya lain untuk menamabah jumlah pengunjung yakni dengan menambah fasilitas seperti Wifi gratis, ruang ber AC dan mendirikan Kafe baca. Unsur cara pandang (world views) yang dimaksud berkaitan dalam proses peningkatan pelayanan maupun pelaksanaan kegiatan layanan yang seringkali terhambat karena anggaran. Bahkan, terkait perencanaan program otomasi 
tersebut tidak mendapat persetujuan dari DPRD setempat karena Perpustakaan Umum Kota Kediri belum mampu melakukan pelayanan yang baik. Dan komponen terhadap hambatan lingkungan dalam proses peningkatan kualitas perpustakaan umum kota kediri adalah tidak adanya dukungan atau perhatian dari Pemda setempat bahkan perpustakaan umum Kota Kediri sebagai tempat "buangan" bagi para birokrat yang ada gap dengan pimpinan Pemda setempat. Komponen yang mempunyai wewenang untuk menghentikan aktivitas dalam prose peningkatan pelayanan perpustakaan umum kota kediri adalah kepala kantor perpustakaan, arsip dan dokumentasi dan kepala seksi pelayanan.

Tabel 1. Definisi Sistem Permasalahan Proses Peningkatan Kualitas Perpustakaan Umum Kota Kediri

\begin{tabular}{|c|c|c|}
\hline No & $\begin{array}{l}\text { Komponen Definisi } \\
\text { Sistem Permasalahan } \\
\text { (CATWOE) }\end{array}$ & $\begin{array}{l}\text { Hasil Definisi Sistem } \\
\text { Permasalahan }\end{array}$ \\
\hline 1 & $\begin{array}{l}\text { Pihak-pihak yang } \\
\text { diuntungkan atau } \\
\text { dirugikan (Clients) }\end{array}$ & Pemustaka \\
\hline 2 & $\begin{array}{l}\text { Pihak-pihak yang } \\
\text { melaksanakan } \\
\text { pemecahan masalah } \\
\text { (Actors) }\end{array}$ & $\begin{array}{l}\text { Pengelola perpustakaan, } \\
\text { pustakawan, Pemustaka }\end{array}$ \\
\hline 3 & $\begin{array}{l}\text { Aktivitas yang } \\
\text { merubah masukan jadi } \\
\text { keluaran } \\
\text { (Transfotrnation } \\
\text { Process) }\end{array}$ & $\begin{array}{l}\text { Peningkatan Kualitas } \\
\text { Pelayanan Perpustakaan }\end{array}$ \\
\hline 4 & $\begin{array}{l}\text { Pemahaman } \\
\text { mendalam dari } \\
\text { berbagai pihak } \\
\text { tentang situasi } \\
\text { permasalahan (World- } \\
\text { view) }\end{array}$ & $\begin{array}{l}\text { Dukungan pendanaan, } \\
\text { adanya program otomasi } \\
\text { dalam layanan, dan } \\
\text { penambahan berbagai } \\
\text { fasilitas }\end{array}$ \\
\hline 5 & $\begin{array}{l}\text { Pihak yang dapat } \\
\text { menghentikan } \\
\text { aktivitas (Owners) }\end{array}$ & $\begin{array}{l}\text { Kepala Perpustaakan, kepala } \\
\text { seksi perpustakaan }\end{array}$ \\
\hline 6 & $\begin{array}{l}\text { Hambatan lingkungan } \\
\text { yang tidak dapat } \\
\text { dihindari } \\
\text { (Environmental } \\
\text { contrains) }\end{array}$ & $\begin{array}{l}\text { Mobilitas mutasi/pergantian } \\
\text { pimpinan perpustakaan } \\
\text { sangat cepat sehingga kurang } \\
\text { mendukung pecepatan } \\
\text { program pengembangan } \\
\text { pelayanan perpustakaan }\end{array}$ \\
\hline
\end{tabular}

\section{Membangun Model Konseptual}

Tahap keempat dalam menerapkan soft system methodology adalah membangun model konseptual (building conceptual models) artinya menggambarkan situasi permasalahan yang terjadi dalam realitas dan upaya pemecahannya dengan membuat tiruannya dalam konseptual. Conceptual Model adalah proses transformasi dari root definition. Model konseptual ini dibangun menggunakan konsep sistem formal (formal system concept) tentang permasalahan yang dihadapi dan upaya pemecahannya dengan menggunakan kerangka berpikir sistem (other system thinking).

Model konseptual dalam proses peningkatan kualitas perpustakaan umum ini dibangun dari sistem formal peningkatan kualitas pelayanan perpustakaan dan definis situasi permasalahan yang terjadi (root definition) pada Perpustakaan Umum Kota Kediri. Pertama, peneliti menggambarkan konsep proses pencapian kualitas perpustakan umum yang meliputi tiga dimensi (input, proses dan outcome). Dimensi input meliputi kecakapan pustakwaan, pengelola, staf layanan, administrasi. Dimensi proses, meliputi proses kualitas perpustakaan melalui kualitas layanan, kualitas koleksi dan kualitas efektif serta efisiensi dalam proses penelusuran sebuah infomasi. Dimensi ketiga, adalah kualitas outcome (layanan perpustakaan yang prima, memuaskan dan koleksi yang bermutu). Ketiga dimensi penentu kualitas perpustakaan secara fundamental merupakan suatu setting dari perpustakaan yang mencerminkan kualitas proses dan outcome. Oleh karena itu rangkaian proses pencapaian mutu perpustakaan adalah adanya input yang memiliki kesiapan mental, adanya proses layanan yang didukung dan disesuaikan dengan kebutuhan pengguna serta menghasilkan outcome yang berkualitas sebagai produk dari rangkaian proses sebelumnya.Kedua, ditindaklanjuti dengan pembuatan model konseptual berdasarkan apa yang terjadi pada realitas (real world) terhadap proses peningkatan kualitas pelayanan perpustakaan umum kota kediri.

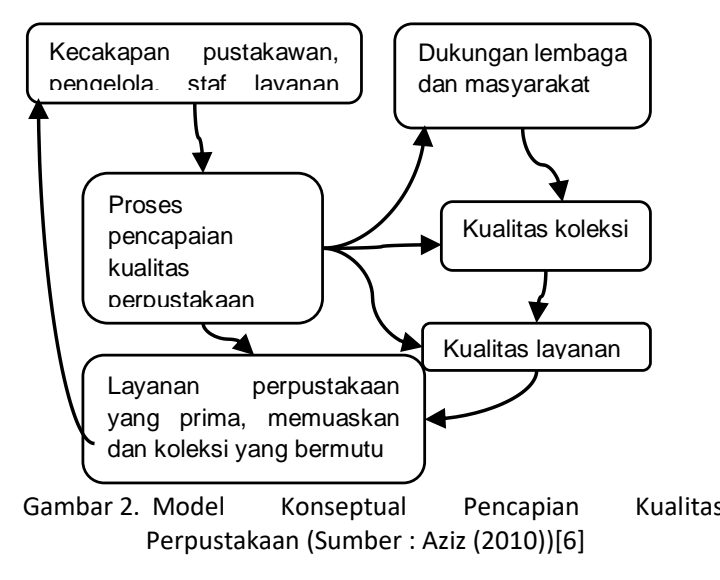

Penjelasan gambar 2 peneliti menggambarkan suatu model konseptual terhadap proses pencapaian kualitas perpustakaan yang dijelaskan Aziz (2010) yang meliputi 3 dimensi input, proses dan outcome. 
Ketiga dimensi ini merupakan suatu rangkaian yang saling berinteraksi dan berketergantungan antara satu yang satu dengan yang lainnya. Dan semua unsur tersebut bekerja dan berorientasi kepada kepuasan dan kebutuhan pemustaka.

Disisi lain, proses peningkatan kualitas pelayanan pada perpustakaan umum khususnya perpustakaan umum kota kediri belum bisa mencapai kualitas pada ketiga unsur tersebut (mutu input, proses, dan outcome). Hal ini dikarenakan, banyaknya permasalahan yang terjadi pada perpustakaan umum kota kediri sehingga sangat mempengaruhi kualitas pelayanan serta belum tercapainya layanan yang memuaskan bagi para pemustaka. Permasalahan dari tahapan input, jumlah pustakawan dan staf yang tidak memadai, struktur organisasi tidak mendukung terhadap kinerja dalam pelayanan (misal, belum adanya unit teknologi informasi, dan unit pembaca), terkendala dalam hal anggaran. Tahapan proses, layanan sirkulasi masih menggunakan sistem manual, kurangnya informasi dalam hal kegiatan layanan. Sehingga, pemustaka merasa belum puas terhadap layanan yang diberikan. Berbagai permasalahan yang terjadi dalam upaya peningkatan kualitas pelayanan pada perpustakaan umum kota kediri digambarkan dalam sebuah model gambar 3 .

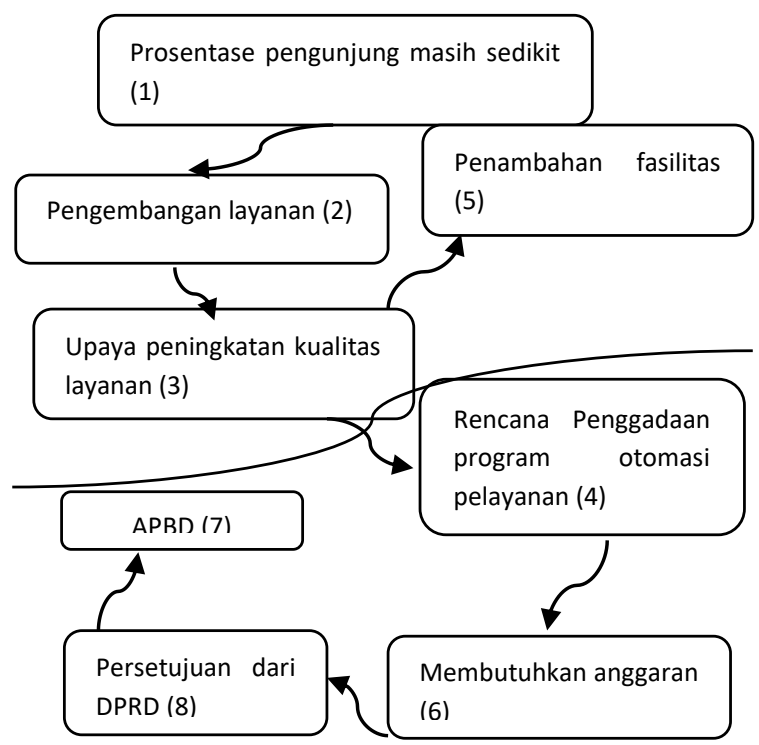

Gambar 3. Model Situasi Permasalahan (Real Word) dalam Proses Peningkatan Kualitas Pelayanan Perpustakaan Umum Kota Kediri (Sumber : data primer)

Penjelasan dari gambar 3 model situasi permasalahan (real word) yang terjadi dalam upaya peningkatan kualitas pelayanan
Perpustakaan Umum Kota Kediri berawal dari kondisi pengunjung masih jauh dari yang diharapkan. Prosentase pengunjung 5, 38\% dari total penduduk Kota Kediri (279.443) pada tahun 2012. Jumlah pengunjung belum mengalami peningkatan yang signifikan dari tahun sebelumnya.

Sehingga, pengelola perpustakaan berusaha untuk meningkatkan kualitas layanan perpustakaan dengan berbagai kegiatan layanan yang disediakan oleh perpustakaan umum, meliputi layanan sirkulasi, layanan perpustakaan keliling, layanan kunjungan dari sekolah, layanan pengarahan katalogisasi pada beberapa kelurahan di Kota Kediri, mengadakan perlombaaan, dan pemeran buku.

Selain itu, pengelola perpustakaan juga menambah berbagai fasilitas misalnya WIFI gratis, membuka kafe baca, ruangan baca ber AC yang diadakan pada tahun 2012. Sistem layanan sirkulasi yang diterapkan adalah sistem terbuka dan manual, dalam kegiatan peminjaman pengelola masih menggunakan sistem pencatatan dan sistem terbuka, yang mana pengunjung bebas memilih koleksi buku yang dikehendaki.

Semua bentuk kegiatan layanan dan rencana program otomasi dalam layanan sirkulasi menjadi program kerja dari perpustakaan dan sumber anggaran dari setiap program kerja tersebut adalah APBD Kota Kediri yang ditetapkan oleh pemerintah berdasarkan persetujuan dari DPRD Kota Kediri. Namun, rencana program layanan otomasi yang dimulai sejak tahun 2010, belum bisa terrealiasasi sampai sekarang karena tidak mendapat persetujuan dari DPRD Kota Kediri. Selain itu, pengelola juga sering mengalami kesulitan dalam proses pencairan anggaran untuk setiap kegiatan layanan perpustakaan.

\section{Perbandingan Antara Model Konseptual Dengan Situasi Permasalahan.}

Berdasarkan pada model konseptual dalam peningkatan kualitas perpustakaan yang terdiri dari 3 dimensi (unsur). Dalam realita yang dihadapi pada perpustakaan umum kota kediri, ketiga unsur tersebut belum bisa mencapai kualitas dari dimensi input sampai outcome. Selain itu, dalam proses peningkatan kualitas pelayanan perpustakaan umum kota kediri, faktor lingkungan (enviromental) kurang mendukung terhadap upaya tersebut. Faktor lingkungan tersebut, berkaitan dengan pemerintah daerah kota kediri kurang memperhatikan dan tidak mendukung terhadap peningkatan kualitas pelayanan. Hal ini dibuktikan, beberapa kali ada 
pergantian pimpinan maupun staf perpustakaan, sehingga sangat mempengaruhi terhadap kinerja dan pengembangan layanan.

Berbagai upaya peningkatan kualitas pelayanan perpustakaan umum sudah dilakukan mulai tahun 2010. Hal ini, berdasarkan dokumen profil Perpustakaan Umum Kota Kediri pada tahun 2010 pengelola berencana membuat program pelayanan otomasi. Namun, dalam realita yang terjadi pengelola menghadapi kendala dengan tidak adanya persetujuan dari DPRD terhadap penggadaan program otomasi di perpustakaan. Sehingga, sampai tahun 2013 program tersebut belum bisa terrealisasi dan layanan sirkulasi menggunakan sistem manual. Risiko atas kehilangan buku jauh lebih besar selama penggunaan sistem manual, karena tidak adanya sistem sensor di pintu masuk dan keluar ruang koleksi.

Oleh karena itu, pengelola tetap berusaha untuk meningkatkan kualitas layanan melalui alternatif kegiatan yang lain yaitu dengan menambah fasilitas wifi gratis, ruangan ber AC dan membuka kafe baca pada tahun 2012. Dan membuat peraturan baru terhadap sistem peminjaman koleksi buku dengan tidak diberlakukan lagi KTA (Kartu Tanda Anggota) tapi menggunakan KTP asli saat melakukan peminjaman. Hal ini bertujuan untuk meminimalisir buku-buku yang tidak dikembalikan oleh pengunjung.

Menurut pandangan peneliti, bahwa upaya peningkatan kualitas pelayanan Perpustakaan Umum Kota Kediri masih bersifat top-down. Artinya, bahwa selama proses peningakatan kualitas layanan, pengelola tidak mengetahui apa yang dikehendaki pengunjung. Dalam hal pelayanan pengunjung menjadi pusat inti dari setiap aktivitas layanan. Penilaian dan kebutuhan pengunjung seharusnya menjadi dasar dari program-program layanan yang akan dilaksanakan oleh perpustakaan. Selama ini Perpustakaan Umum Kota Kediri belum pernah melakukan survey atau analisa kebutuhan dari pemustaka atau pengunjung. Oleh karena itu, pada tahapan selanjutnya dalam analisa soft system methodology ini akan dilakukan sebuah upaya perbaikan terhadap model peningkatan kualitas layanan perpustakaan umum.

\section{E. Perubahan Model Yang Diinginkan.}

Bagian ini menjelaskan tentang proses yang telah dilakukan dalam upaya menyempurnakan model konseptual proses peningkatan kualitas pelayanan umum kota kediri. Penjelasan ini dipandang penting untuk memahami proses penggunaan analisis soft systems methodology yang telah dilaksanakan, dan membantu memahami model sistem peningkatan kualitas pelayanan perpustakaan umum.

Penyempurnaan model konseptual dilakukan dalam dua tahap. Pertama, membandingkan model konseptual dengan realitas permasalahan yang dihadapi dalam proses peningkatan kualitas perpustakaan umum. Kedua, mendefinisikan perubahan yang diinginkan stakeholder agar model yang dibangun dapat ditindaklanjuti dengan kegiatan aksi.

Hasil perbandingan menunjukan bahwa model konseptual peningkatan kualitas perpustakaan umum yang telah dilakukan masih terdapat perbedaan dengan realitas yang dihadapi. Dalam model konseptual, tahapan analisa kebutuhan pemustaka dan pendanaan merupakan "core" atau inti dalam menentukan program-program pelayanan yang akan dilaksanakan belum termasuk pada tahapan input. Selain itu, proses peningkatan kualitas pelayanan perpustakaan umum, realitasnya belum dilaksanakan menyeluruh dari semua sistem yang terlibat. Proses peningkatan kualitas hanya dilakukan sepihak oleh pengelola perpustakaan tanpa melibatkan pemustaka. Maksudnya, input atau tahapan awal dari proses peningkatan kualitas adalah melakukan analisa kebutuhan pemustaka sebelum melakukan sebuah perencaaan program. Analisa kebutuhan bisa dilakukan dalam bentuk kegiatan survey pemustaka.

Selanjutnya, pada tahapan kegiatan pelayanan masih minimnya sosialiasi kepada masyarakat akan kegiatan pelayanan yang dilakukan oleh perpustakaan. Kurang adanya inisiatif dari pengelola untuk memanfaatkan teknologi informasi misalnya melalui web, media sosial, blog sebagai sarana sosialisasi atau promosi kegiatan pelayanan perpustakaan. Realita yang dihadapi oleh pengelola perpustakaan umum berkaitan masalah anggaran. Karena sistem anggaran perpustakaan umum bersumber dari anggaran daerah, sehingga pengelola akan berhadapan dengan proses birokrasi yang panjang untuk mencairkan anggaran yang akan digunakan untuk melakukan pelayanan kepada masyarakat. Sehingga dalam pihak pengelola mengalami hambatan dalam menjalankan pelayanan. Sebagai contoh, pelayanan perpustakaan keliling yang terjadwal setiap hari selasa dan kamis belum bisa terlaksana secara rutin karena dana untuk pembelian bensin tidak ada. 
Upaya pengelola untuk menerapkan program otomasi juga terhambat oleh permasalahan anggara dan tidak adanya dukungan dari DPRD setempat. Program otomasi yang direncanakan sejak tahun 2010 belum bisa terrealisasi sampai tahun 2013. Dan, dibukanya kafe baca yang bertujuan untuk meningkatkan jumlah pengunjung, dirasa kurang efektif. Karena terlihat di lapangan, kafe baca tidak rutin dibuka. Dan pengunjung jarang menggunakan fasilitas tersebut. Selain itu, dinamisasi pergantian pimpinan dan kondisi beberapa staf tidak pernah menjalankan tugasnya sangat mempengaruhi terhadap pelaksanaan program-program pelayanan Perpustakaan Umum Kota Kediri. Dengan 8 staf yang aktif termasuk 2 pustakawan, belum optimal untuk mengelola Perpustakaan Umum Kota Kediri.

Dengan demikian, perlu dilakukan upaya perbaikan model dalam proses peningkatan perpustakaan khususnya perpustakan umum kota kediri yang lebih aplikatif. Merupakan integrasi dan harmonisasi antara setiap tahapan dengan bentuk layanan yang diberikan kepada pemustaka. Mengingat pemustaka merupakan unsur utama dalam manjemen pelayanan. artinya, bahwa setiap tahapan proses pelayanan berorientasi pada pemustaka.

Komponen model sistem proses peningkatan kualitas pelayanan perpustakaan umum tiga komponen dasar. Pertama, komponen realitas yang dihadapi. Kedua, komponen kerangka berpikir sistem dalam rangka memecahkan masalah yang dihadapi. Ketiga adalah konsistensi terhadap tahapan proses peningkatan kualitas pelayanan. Berikut adalah perubahan model yang dinginkan dalam sistem proses peningkatan kualitas perpustakaan umum pada gambar 4.

Memahami Gambar 4 dapat dijelaskan bahwa proses peningkatan kualitas pelayanan perpustakaan umum diawali dengan memahami kebutuhan apa yang dikehendak oleh pemustaka dan tujuan dari upaya ini adalah untuk mencapai layanan prima. Dengan memberlakukan pemustaka sebagai raja menjadi senjata ampuh untuk meningkatkan kepercayaan masyarakat terhadap layanan perpustakaan. Hal ini penting karena perpustakaan akan meningkat citranya di mata masyarakat apabila dapat memuaskan pemustakanya. Pemustaka atau pengguna perpustakaan umum memiliki karakteristik dan tingkat pendidikan yang beragam. Pemustaka merupakan inti (core) atau pusat dari organisasi, sehingga kebutuhan pemustaka menentukan kegiatan layanan yang dilaksanakan oleh pengelola perpustakaan. Dengan demikian, setiap pemustaka wajib diperlakukan dan dipenuhi kebutuhannya dengan cara berbeda pula.

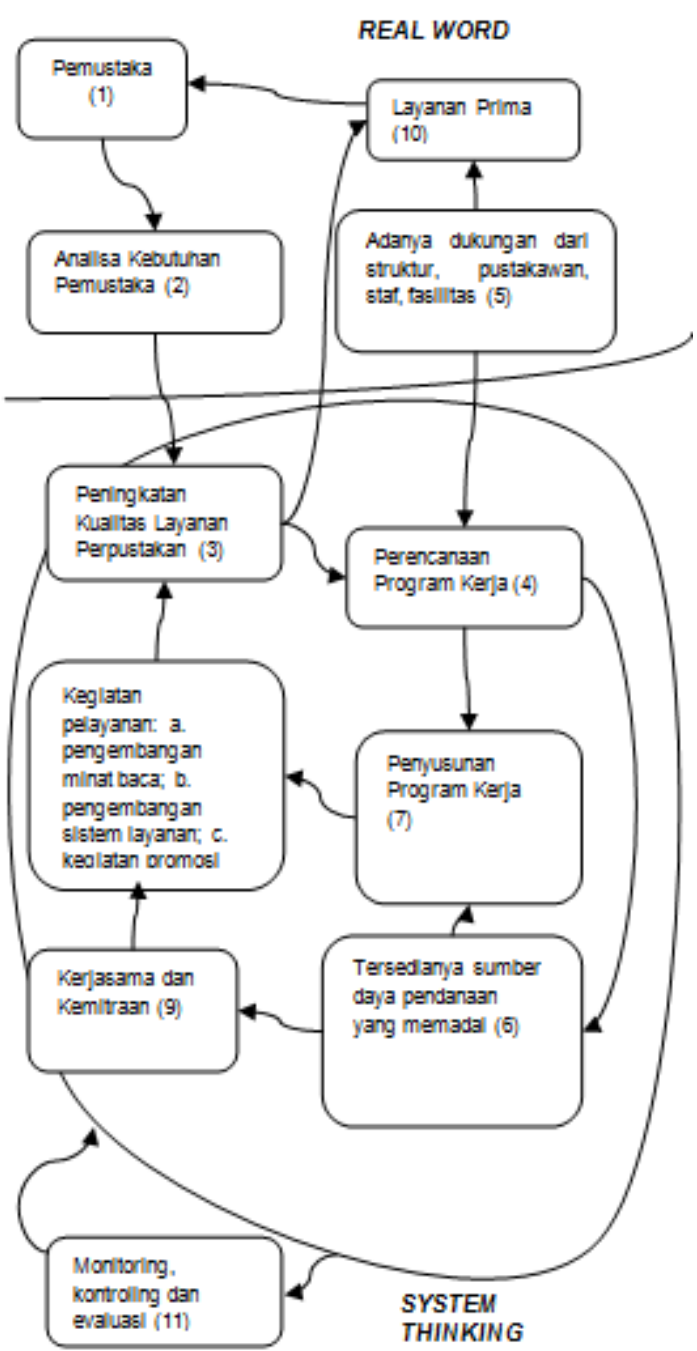

Gambar 4. Model Sistem Proses Peningkatan Kualitas Perpustakaan Umum (Sumber: data primer)

Memahami Gambar 4 dapat dijelaskan bahwa proses peningkatan kualitas pelayanan perpustakaan umum diawali dengan memahami kebutuhan apa yang dikehendak oleh pemustaka dan tujuan dari upaya ini adalah untuk mencapai layanan prima. Dengan memberlakukan pemustaka sebagai raja menjadi senjata ampuh untuk meningkatkan kepercayaan masyarakat terhadap layanan perpustakaan. Hal ini penting karena perpustakaan akan meningkat citranya di mata masyarakat apabila dapat memuaskan pemustakanya. Pemustaka atau pengguna perpustakaan umum memiliki karakteristik dan tingkat pendidikan yang beragam. Pemustaka merupakan inti (core) atau pusat dari organisasi, 
sehingga kebutuhan pemustaka menentukan kegiatan layanan yang dilaksanakan oleh pengelola perpustakaan. Dengan demikian, setiap pemustaka wajib diperlakukan dan dipenuhi kebutuhannya dengan cara berbeda pula.

Untuk mengetahui dan memahami kebutuhan pemustaka. Perlu dilakukan analisa kebutuhan, dilaksanakan melalui survey dengan mengadakan interview, pengisian angket atau pengisian form. Kegiatan survey bisa dilakukan setiap setahun sekali. Devadson dan Lingam (1996) mengatakan: “ Konsep kebutuhan informasi merupakan kesatuan dari studi pemustaka, lingkungan dan informasi yang digunakan. Hal ini merupakan penelitian perpustakaan dan informasi paling penting selama lebih dari empat puluh tahun" [4]. Maka untuk mengetahui kebutuhan informasi ada tiga hal yang perlu diketahui, yaitu: 1) pemustaka terutama karakternya, 2) lingkungan dimana pemustaka itu menghabiskan waktunya: di kantor, di perusahaan, di pabrik, di sekolah dan lain-lain, 3) jenis infomasi yang dimanfaatkan.

Selanjutnya, hasil dari survey terhadap pemustaka akan dijadikan masukan (input) untuk penyusunan program kerja dan rencana penggadaan koleksi buku. Dengan memperhatikan secara khusus, maka kebutuhan pemustaka akan dapat dipenuhi dengan baik. Pemustaka akan merasa puas dan ia akan bersedia menjadi duta perpustakaan. la secara alamiah akan berbicara tentang kebaikan layanan perpustakaan kepada teman-temannya. Dampak positif kepada perpustakaan akan luar biasa, karena metode penyampaian dari mulut ke mulut mempunyai potensi penyebaran cukup mengesankan. Kebaikan perpustakaan akan didengar oleh orang banyak yang akhirnya mereka akan termotivasi untuk memanfaatkan layanan, fasilitas, dan koleksi perpustakaan.

Tahapan di atas merupakan input dari proses peningkatan kualitas pelayanan perpustakaan umum termasuk dalam system thinking. Tahapan proses itu sendiri meliputi tahapan perencanaan program kerja perpustakaan. Dalam perencanaan program kerja, pengelola terlebih dahulu menganalisa kebutuhan pemustaka dan merencanakan sumber daya yang dibutuhkan (tenaga, sumber dana, fasilitas) dan dukungan dari struktur organisasi dan fungsi pada setiap unit atau bagian organisasi dalam menjalankan tugas, wewewang dan peran masing-masing akan berjalan efektif apabila didukung dengan beberapa persyaratan nilai birokrasi. Nilai yang dimaksud adalah adanya satuan komando, berfungsinya institusi berdasarkan hierarki, institusi mampu bekerja secara profesional, dan institusi mampu melaksanakan fungsi secara efektif dan efisien. Pada tahapan perencanan program, mindset (pola pikir) para pengelola harus dibangun bahwa apa yang mereka rencanakan tersebut berorientasi pada layanan prima (layanan yang dapat memuaskan pemustaka). Selain itu, perpustakaan umum melaksanakan setiap program, penggadaan fasilitas, pengembangan layanan dan melaksanakan prosedur pelayanan sebaiknya berdasarkan standar nasional perpustakaan umum.

Semua proses peningkatan kualitas pelayanan tersebut tidak akan berjalan efektif apabila tidak ada dukungan pendanaan. Sumber pendanaan perpustakaan seharusnya tidak hanya bergantung pada APBD, namun perpustakaan bisa mengupayakan suatu kerjasama dan kemitraan dengan instansi pemerintah lainnya, pihak swasta dan para donatur. Kerjasama dan kemitraan ini bisa dilakukan dengan penggadaan fasilitas maupun penggadaan koleksi di perpustakaan. Kerjasama dan kemitraan ini bertujuan untuk mendukung dan meningkatkan program-program pelayanan dan menambah fasilitas perpustakaan. Sehingga, perpustakaan umum tidak hanya menggandalkan sumber anggran dari pemerintah, namun juga berusaha melakukan kemitraan dengan pihak swasta melalui program pendidikan dalam upaya peningkatan pelayanan terhadap perpustakaan umum.

Tahapan perencanaan program dan komponen pendukung yang telah dijelaskan di atas saling berhubungan dan berinteraksi. Kemudian, menjadi dasar untuk melakukan penyusunan terhadap program kerja. Dalam penyusunan program kerja, adanya penetapan waktu untuk memudahkan pelaksanaan setiap program dan target tercapinya program tersebut. Sebagai patokan mengenai lamanya dapat diklasifikasikan sebagi berikut: a) program kerja jangka pendek dikerjakan selama 6 sampai dengan 12 bulan (1 tahun); b) program jangka sedang atau menengah dikerjakan selama 13 sampai dengan 36 bulan (3 tahun); c) program jangka panjang dikerjakan selama 37 bulan atau 3 tahun lebih ke atas. Penetapan waktu ini pada akkhirnya tergantung kepada kepala perpustakaannya, apakah akan disesuaikan dengan masa jabatannya ataukah disusun ideal dengan tidak mengingat masa jabatannya.

Setelah melalui proses perencanaan dan penyusunan program kerja perpustakaan umum, 
kemudian dilanjutkan dengan pelaksanaan program dalam bentuk kegiatan pelayanan. Kegiatan pelayanan perpustakaan umum, meliputi:

\section{a. Pengembangan minat baca}

Kegiatan pengembangan minat baca terusmenerus dilakukan, mengingat minat baca masyarakat kota kediri masih rendah. Dengan demikiaan, pengembangan mina baca harus dilakukan melalui layanan sirkulasi yang berkualitas. Selain itu, perpustakaan umum kota bisa menjadi fasilitator untuk membentuk komunitas baca di masing-masing kelurahan di Kota Kediri. Komunitas baca ini bisa melibatkan para penulis buku, mahasiswa, dan LSM.

b. Pengembangan sistem layanan.

Pengembangan sistem layanan merupakan layanan pendukung selain layanan referensi. Kegiatan layanan tersebut disesuaikan dengan kebutuhan dan kultural masyarakat kota kediri. Misalnya, pelayanan informasi lowongan kerja, kegiatan untuk komunitas penulis, pelatihan atau workshop karya tulis untuk mahasiswa, pelajar, kegiatan story telling bagi anak-anak dan mengadakan lomba-lomba (lomba mendongeng cerita rakyat, lomba tari lokal, lomba menulis cerita rakyat, menulis puisi tentang budaya setempat.

\section{c. Kegiatan Promosi}

Tahapan selanjutnya adalah kegiatan promosi. Promosi perpustakaan, yaitu usahausaha yang dilakukan pihak perpustakaan untuk memperkenalkan sesuatu yang berkaitan dengan manfaat dan cara menggunakan perpustakaan kepada sekelompok orang atau masyarakat. Sarana promosi bisa dilakukan dengan memanfaatkan kemajuan teknologi informasi, melalui media sosial, website, komunitas blogger, dan sebagainya.

Semua kegiatan layanan di atas merupakan hasil (output) dari suatu rangkaian proses peningkatan kualitas pelayanan perpustakaan umum. Dan seluruh komponen dalam kegiatan layanan tersebut diorientasikan menuju layanan prima (memberikan layanan yang terbaik untuk pemustaka)

Tahapan proses peningkatan kualitas perpustakaan umum di atas diharapkan dapat meghasilkan outcome berupa layanan prima yaitu layanan terbaik yang memuaskan pelanggan, sesuai standar, dan bahkan melebihi standar dari sebuah pedoman pelayanan. Sebagaimana dalam UU Nomor 43 Tahun 2007 mewajibkan untuk memberi layanan prima kepada pemustaka. Pasal 32 ayat a berbunyi : "Tenaga perpustakaan berkewajiban memberikan layanan prima terhadap pemustaka". Untuk itu perlu bagi tenaga perpustakaan memiliki ketrampilan dan pengetahuan, disamping penampilan fisik yang menyenangkan. Sebuah layanan dinilai prima jika mematuhi beberapa prinsip. Prinsip merupakan tata nilai yang harus melekat pada layanan prima.

Semua proses tahapan di atas yang termasuk dalam system thinking memerlukan adanya kontroling dan evaluasi dari pengelola perpustakaan. Tahapan ini merupakan salah bentuk dari komitmen pengelola perpustakaan untuk konsisten menjalankan semua tahapan tersebut guna mencapai keberhasilan pelayanan yang diharapkan. Apabila dalam tahapan kontroling, evaluasi terjadi permasalahan dari sumber daya. Maka, diperlukan suatu pembinaan terhadap unsur sumber daya tersebut yakni pembinaan terhadap organisasi. Pada struktur organisasi Perpustakaan Umum Kota Kediri sebaiknya melakukan pengembangan dalam bagan struktur yang sudah ada menjadi lebih besar guna menampung perkembangan volume kegiatan yang semakin besar, yakni dengan menambahkan unit layanan pembaca atau pemustaka, unit layanan teknis, dan unit layanan teknologi informasi. Selanjutnya, pembinaan ketenagaan, bisa dilakukan dengan pemberian reward, mengadakan training outbond, dan pelatihan skill dan wawasan.

Model proses peningkatan kualitas pelayanan perpustakaan umum yang telah dijelaskan di atas, secara garis besar dapat disederhanakan menjadi sebuah model LSQ (Library Service Quality) yang terdiri dari 3 tahapan dan unsur inti (core) dari proses peningkatan kualitas pelayanan perpustakan umum (gambar 5).

Penerapan model LSQ merupakan tahapan proses peningkatan kualitas pelayanan perpustakaan umum, meliputi 3 (tiga) tahapan antara lain: tahapan pertama disebut input (masukan) yang terdiri dari beberapa unsur atau komponen seperti halnya analisa kebutuhan pemustaka, dukungan struktur, sumber daya manusia dan anggaran. Tahapan kedua, disebut process (proses) merupakan suatu aktivitas atau sistem kegiatan yang dilaksanakan untuk mencapai hasil yang diharapkan. Dalam tahapan proses berdasarkan indikator ' 3 Es' (efficacy, effectiveness, efficiency). Tahapan ketiga, disebut output (keluaran) merupakan hasil yang diharapkan yakni berupa kegiatan layanan. Dalam ketiga prose tersebut akan menghasilkan suatu outcome untuk mencapai layanan prima dalam 
pelayanan perpustakaan umum. Ketiga tahapan saling berinterakasi dan saling mempengaruhi, dalam tahapan outcome (layanan prima) yaitu tanggapan atau penilaian dari pemustaka akan kembali kepada tahapan awal (input).

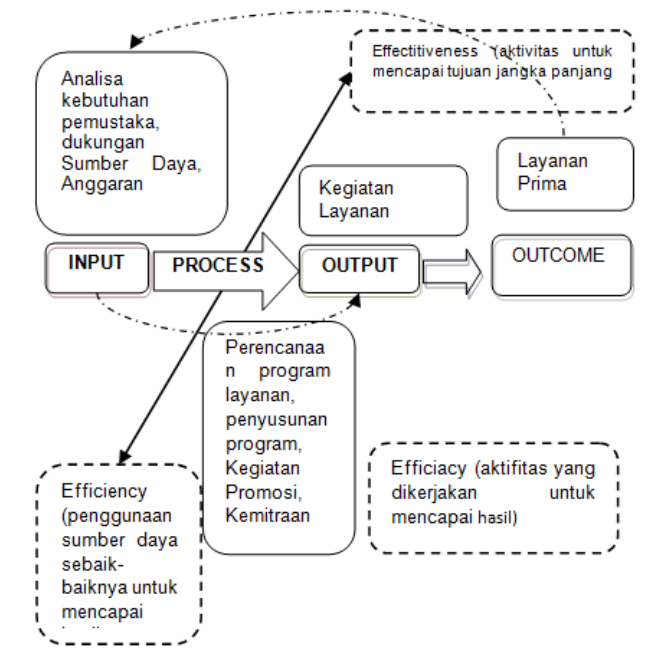

Gambar 5. Model LSQ (Library Service Quality) (Sumber: peneliti)

Penerapan model LSQ merupakan tahapan proses peningkatan kualitas pelayanan perpustakaan umum, meliputi 3 (tiga) tahapan antara lain: tahapan pertama disebut input (masukan) yang terdiri dari beberapa unsur atau komponen seperti halnya analisa kebutuhan pemustaka, dukungan struktur, sumber daya manusia dan anggaran. Tahapan kedua, disebut process (proses) merupakan suatu aktivitas atau sistem kegiatan yang dilaksanakan untuk mencapai hasil yang diharapkan. Dalam tahapan proses berdasarkan indikator ' 3 Es' (efficacy, effectiveness, efficiency). Tahapan ketiga, disebut output (keluaran) merupakan hasil yang diharapkan yakni berupa kegiatan layanan. Dalam ketiga prose tersebut akan menghasilkan suatu outcome untuk mencapai layanan prima dalam pelayanan perpustakaan umum. Ketiga tahapan saling berinterakasi dan saling mempengaruhi, dalam tahapan outcome (layanan prima) yaitu tanggapan atau penilaian dari pemustaka akan kembali kepada tahapan awal (input).

\section{KESIMPULAN DAN SARAN Kesimpulan}

Manajemen pelayanan diperlukan oleh organisasi untuk meningkatkan kualitas pelayanan dan mempertahankan keberlangsungan hidup organisasi tersebut. Unsur manajemen pelayanan meliputi: sumber daya, sistem layanan perpustakaan, dan pengguna jasa. Setiap unsur manjemen pelayanan Perpustakaan Umum Kota Kediri belum secara optimal memprioritaskan kebutuhan layanan bagi penggunanya. Hal ini dikarenakan banyak permasalahan yang terjadi pada setiap unsur dalam manajemen pelayanan perpustakaan umum kota kediri.

Penilaian kualitas pelayanan perpustakaan merupakan suatu keharusan bagi organisasi tersebut, dan penilaian tersebut tidak hanya berasal dari internal organisasi (pengelola), tetapi penilaian terhadap kualitas seharusnya juga dilakukan terhadap para pengguna layanan.

$$
\text { Pembuatan model peningkatan }
$$

peningkatan kualitas pelayanan perpustakaan umum menggunakan metodologi sistem lunak yang terdiri dari tujuh tahapan. Secara garis besar, operasionalisasi metodologi tersebut dikelompokan menjadi tiga tahap. Pertama, memahami masalah yang dihadapi dengan cara menggali masalah yang tidak terstruktur secara mendalam dan ditindaklanjutin dengan strukturisasi masalah (problem structural). Memahami masalah peningkatan kualitas pelayanan perpustakaan umum berdasarkan manjemen pelayanan yang terjadi pada Perpustakaan Umum Kota Kediri. Manajemen pelayanan tersebut, meliputi 3 (tiga unsur) yakni sumber daya, sistem pelayanan dan penilaian pengunjung terhadap layanan perpustakaan. Penjelasan dari model proses peningkatan kualitas pelayanan perpustakaan umum diawali dengan memahami kebutuhan apa yang dikehendak oleh pemustaka. Dengan memberlakukan pemustaka sebagai raja menjadi senjata ampuh untuk meningkatkan kepercayaan masyarakat terhadap layanan perpustakaan. Hal ini penting karena perpustakaan akan meningkat citranya di mata masyarakat apabila dapat memuaskan pemustakanya. Pemustaka atau pengguna perpustakaan umum memiliki karakteristik dan tingkat pendidikan yang beragam. Pemustaka merupakan inti (core) atau pusat dari organisasi, sehingga kebutuhan pemustaka menentukan kegiatan layanan yang dilaksanakan oleh pengelola perpustakaan. Dengan demikian, setiap pemustaka wajib diperlakukan dan dipenuhi kebutuhannya dengan cara berbeda pula.

Untuk mengetahui dan memahami kebutuhan pemustaka. Perlu dilakukan analisa kebutuhan, dilaksanakan melalui survey dengan mengadakan interview, pengisian angket atau pengisian form. Tahapan di atas merupakan input dari proses peningkatan kualitas pelayanan 
perpustakaan umum. Tahapan proses itu sendiri meliputi tahapan perencanaan program kerja perpustakaan. Perencanaan program kerja berdasarkan hasil dari analisa kebutuhan pemustaka dan merencanakan sumber daya yang dibutuuhkan (tenaga, sumber dana, fasilitas)

Program kerja perpustakaan umum akan menjadi acuan dan dilaksanakan dalam berbagai bentuk kegiatan pelayanan. Kegiatan pelayanan perpustakaan umum, meliputi: a. Pengembangan minat baca; b. Pengembangan sistem layanan; c. Kegiatan Promosi. Selain dari sumber pendanaan, perlu dilakukan suatu pembinaan terhadap sumber daya yang lainnya. Seperti halnya, dilakukan pembinaan terhadap organisasi, pada strukutur organisasi Perpustakaan Umum Kota Kediri sebaiknya melakukan pengembangan dalam bagan struktur yang sudah ada menjadi lebih besar guna menampung perkembangan volume kegiatan yang semakin besar, yakni dengan menambahkan unit layanan pembaca atau pemustaka, unit layanan teknis, dan unit layanan teknologi informasi. Tahapan proses peningkatan kualitas perpustakaan umum di atas tidak akan berjalan optimal apabila tidak dibarengin dengan adanya, kontroling dan evaluasi dari pengelola perpustakaan.

Model proses peningkatan kualitas pelayanan perpustakaan umum yang telah dijelaskan di atas, secara garis besar dapat disederhanakan menjadi sebuah model LSQ (Library Service Quality) yang terdiri dari 3 tahapan dan unsur inti (core) dari proses peningkatan kualitas pelayanan perpustakaan umum, yakni tahapan input (meliputi sumber daya), tahapan proses dan tahapan output (layanan prima).

Saran

Proses peningkatan kualitas perlu adanya komitmen dan konsistensi pengelola untuk melaksanakan setiap tahapan. Selain itu, dalam proses peningkatan kualitas pelayanan perpustakaan umum tidak akan berjalan efektif apabila tidak ada dukungan pendanaan. saran peneliti terhadap Perpustakaan Umum di Indonesia dan khususnya Perpustakaan Umum Kota Kediri perlu mengadakan suatu kemitraan dengan pihak-pihak swasta dalam hal penyediaan fasilitas dan pelayanan perpustakaan.

\section{UCAPAN TERIMA KASIH}

Alhamdulilah, berkat segenap rahmat dan pertolongan Allah SWT serta dukungan dari berbagai pihak, penulis dapat menyelesaikan jurnal ini. Untuk itu, penulis menyampaikan ucapan terima kasih yang sebesar-besarnya kepada: Dr. M.R Khairul Muluk, M.Si, selaku Komisi Pembimbing dan Dr. Irwan Noor, MA selaku anggota Komisi Pembimbing, yang telah meluangkan waktu dan memberikan bimbingan, ilmu, wawasan, inspirasi, serta motivasi dalam penulisan tesis ini. Dan Kepala Seksi dan staf Perpustakaan Umum Kota Kediri atas kesempatan yang diberikan kepada penulis untuk menempuh pendidikan Strata-2.

\section{DAFTAR PUSTAKA}

[1]. Martoatmojo, Karmidi. 2009. Pelayanan Bahan Pustaka. Jakarta. Universitas Terbuka.

[2]. Rowley, Jennifer. 2010. "Should your library have an innovation strategy?". Library Management". Vol. 32 Iss: 4 pp. 251 - 265. Emerald Group Publishing.

[3]. Checkland and Scholes. 1990. Soft syatem Methodology in Action. Chichester John Wiley \& Sons.

[4]. Achmad; Mansur Sutedjo; Surono; Edy Suprayitno. 2012. Layanan CintaPerwujuadan Layanan Prima ${ }^{++}$ Perpustakaan. Jakarta. Cv Sagung Seto

[5]. Keputusan Menteri Pendayagunan Aparatur Negara No.63/KEP/M.PAN/7/2003 tentang Pedoman Umum Penyelenggaraan Pelayanan Publik

[6]. Aziz, Safrudin. 2010. Strategi Peningkatan Mutu Pada Perpustakaan Perguruan Tinggi. Sekolah Tinggi Agama Islam Negeri. Purwokerto. Akses dari www.pnri.go.id\%2FiFileDownload.aspx\%3FI D\%3DAttachment\%255CMajalahOnline\%25 5CSafrudin_Aziz_Strategi_Peningkatan_Mut u.pdf\&ei=IFBbUu_fEYiSrgeH7ICQDQ\&usg=A FQjCNFyvb3_LpZBmbEwf-NhrvvSr2SBGg/ 14 Oktober 2013 